\title{
Postsurgical peritoneal inclusion cyst masquerading as a large pelvic mass
}

\author{
Nigel Pereira
}

The Ronald 0 Perelman and Claudia Cohen Center for Reproductive Medicine, Weill Cornell Medical College, New York City, New York, USA

\section{Correspondence to} Dr Nigel Pereira,

Accepted 27 March 2019 nip9060@med.cornell.edu

\section{DESCRIPTION}

A 34-year-old gravida 0 woman presented to the office for an infertility consultation. Her gynaecological history was significant for endometriosis and pelvic pain, for which she had undergone robot-assisted laparoscopic endometriosis resection, presacral neurectomy, lysis of adhesions and an appendectomy approximately 6 years ago. Her hysterosalpingogram and ovarian reserve testing 5 months prior was normal. Transvaginal ultrasonography in the office revealed a clear, fluid-filled mass in the posterior cul-de-sac (figure 1A). The mass appeared distinct from both ovaries (figure 1B,C).

MRI of the pelvis was performed, which showed a large loculated mass measuring $107.4 \times 76.9 \mathrm{~mm}$ in the posterior cul-de-sac (figure $2 \mathrm{~A}, \mathrm{~B}$ ). The mass contained thin septations. No enhancing peritoneal nodules were noted. Her tumour markers were negative. A large peritoneal inclusion cyst was suspected at the site of the prior surgery and the patient was scheduled for laparoscopic drainage and excision of the cyst at an outside institution. However, spontaneous rupture of the cyst occurred prior to laparoscopy. The peritoneal inclusion cyst did not recur over a 4-month observation period.

Peritoneal inclusion cysts are one of the most commonly diagnosed non-ovarian cystic pelvic lesions. ${ }^{12}$ Often seen in women of reproductive age, peritoneal inclusion cysts can be unilocular or septated, have minimally enhancing walls and may abut or surround one or both ovaries, which generally appear normal. ${ }^{12}$ Risk factors for these inclusion cysts, as exemplified in this case, include prior abdominal or pelvic surgery, trauma, pelvic inflammatory disease or endometriosis. ${ }^{12}$ Peritoneal inclusion cysts are typically lined by a single layer of flat to cuboidal mesothelial cells, which have bland nuclear

(C) BMJ Publishing Group Limited 2019. No commercial re-use. See rights and permissions. Published by BMJ.

\begin{tabular}{l}
\hline To cite: Pereira N. BMJ Case \\
Rep 2019;12:e230066. \\
doi:10.1136/bcr-2019- \\
230066 \\
\hline
\end{tabular}

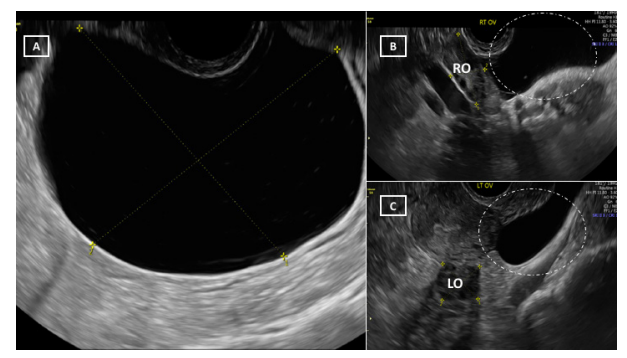

Figure 1 Transvaginal ultrasonography, sagittal section. (A) A large, fluid-filled pelvic mass measuring $61.6 \times 64.6 \mathrm{~mm}$ is noted in the posterior cul-de-sac. (B) The right ovary (RO) is noted to be distinct from the mass (dotted white circle). (C) The left ovary (LO) is noted to be distinct from the mass (dotted white circle).

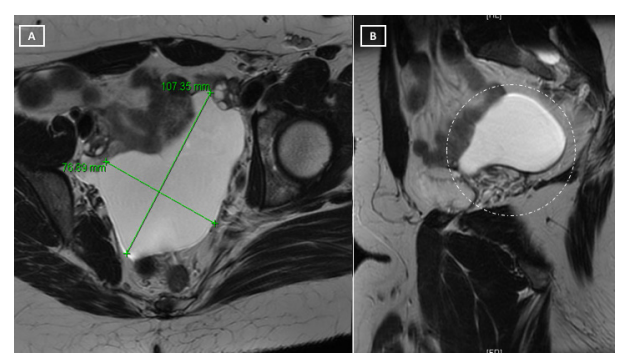

Figure 2 (A) T2-weighted MRI, axial section. The fluid-filled peritoneal inclusion cyst is marked with green callipers. (B) T2-weighted MRI, sagittal section. The fluidfilled peritoneal inclusion cyst is shown (dotted white circle).

features. $^{34}$ The septa may consist of loose fibrovascular connective tissue and sparse inflammatory infiltrate. ${ }^{3}$ At times, unusual morphological features may raise suspicion for malignancy, though they are largely benign. ${ }^{34}$ It is thought that peritoneal tissue may generate proliferative reactions secondary to intra-abdominal inflammation or injury, resulting in cyst formation. ${ }^{3}$ While the normal peritoneum can easily absorb physiological peritoneal or pelvic fluid, injury to the peritoneal tissue can impair its ability to absorb any fluid produced physiologically in the pelvic cavity. ${ }^{3}$ Differential diagnoses for peritoneal inclusion cysts include other tumour-like lesions of the peritoneum such as mesothelial hyperplasia, non-granulomatous histiocytic lesions, granulomatous lesions and Müllerian lesions. ${ }^{4}$ Treatment options for peritoneal inclusion cysts depend on clinical symptoms. Ultrasonographic observation is preferred in asymptomatic

\section{Patient's perspective}

My case and clinical history can highlight how MRI can be used to diagnose an inclusion cyst in the pelvis.

\section{Learning points}

- Peritoneal inclusion cysts are one of the most commonly diagnosed pelvic lesions not emanating from the ovary.

- Peritoneal inclusion cysts may often grow very large, necessitating radiological or laparoscopic evaluation.

- Risk factors for these cysts include prior pelvic surgery, endometriosis or pelvic inflammatory disease. 
patients. ${ }^{3}$ Drainage or aspiration of cysts is a safe and minimally invasive option for persistent cysts. Surgical management in the form of laparoscopy or laparotomy with complete removal of the cyst is generally indicated whenever there is any suspicion of malignancy. ${ }^{3} 4$

Contributors NP drafted the manuscript and obtained all clinical images.

Funding The authors have not declared a specific grant for this research from any funding agency in the public, commercial or not-for-profit sectors.

Competing interests None declared.

Patient consent for publication Obtained.

Provenance and peer review Not commissioned; externally peer reviewed.
Author note The current manuscript was written based on the 13-item CARE checklist for case reports.

\section{REFERENCES}

1 Moyle PL, Kataoka MY, Nakai A, et al. Nonovarian cystic lesions of the pelvis. Radiographics 2010;30:921-38.

2 Thawait SK, Batra K, Johnson SI, et al. Magnetic resonance imaging evaluation of non ovarian adnexal lesions. Clin Imaging 2016;40:33-45.

3 Rapisarda AMC, Cianci A, Caruso S, et al. Benign multicystic mesothelioma and peritoneal inclusion cysts: are they the same clinical and histopathological entities? A systematic review to find an evidence-based management. Arch Gynecol Obstet 2018:297:1353-75.

4 Baker PM, Clement PB, Young RH. Selected topics in peritoneal pathology. Int J Gynecol Pathol 2014:33:393-401.

Copyright 2019 BMJ Publishing Group. All rights reserved. For permission to reuse any of this content visit

https://www.bmj.com/company/products-services/rights-and-licensing/permissions/

BMJ Case Report Fellows may re-use this article for personal use and teaching without any further permission.

Become a Fellow of BMJ Case Reports today and you can:

- Submit as many cases as you like

- Enjoy fast sympathetic peer review and rapid publication of accepted articles

- Access all the published articles

Re-use any of the published material for personal use and teaching without further permission

For information on Institutional Fellowships contact consortiasales@bmjgroup.com

Visit casereports.bmj.com for more articles like this and to become a Fellow 